\title{
Utilization of urea nitrogen for albumin synthesis in the stagnant loop syndrome
}

\author{
RAE VARCOE, D. HALLIDAY, AND A. S. TAVILL \\ From the MRC Clinical Research Centre, Watford Road, Harrow, Middlesex
}

SUMMARY A study of urea and albumin metabolism was carried out in a patient with the stagnant loop syndrome and in a control subject using radioisotopic and stable isotopic techniques. The patient had a higher rate of urea synthesis, urea hydrolysis in the gut, and of incorporation of recycled urea nitrogen into albumin. Although only a small proportion $(0.4 \%)$ of the urea nitrogen available was used for albumin synthesis and this constituted only $0.8 \%$ of the daily nitrogen requirement for this purpose, the reutilization of nitrogen was relatively much greater than was observed in the control study.

Hypoalbuminaemia is a well recognized complication of the stagnant loop syndrome (Krikler and Schrire, 1958; Neale, Antcliff, Welbourn, Mollin, and Booth, 1967). In a detailed study of a patient with this condition Jones, Craigie, Tavill, Franglen, and Rosenoer (1968) showed that this was due to low hepatic albumin synthesis, which was associated with an unexpectedly high rate of urea synthesis. Furthermore, only $33 \%$ of the synthesized urea appeared in the urine, suggesting a very high rate of degradation of urea. An implication which has not previously been investigated is the extent to which the bacterial flora may make urea nitrogen available for hepatic protein synthesis.

We have been able by means of combined radioisotopic and stable isotopic techniques to study this aspect of disordered protein metabolism in a further patient with a proven stagnant loop syndrome. It has been possible to study simultaneously the rate of urea synthesis and the rate of albumin degradation under steady state conditions while at the same time observing the incorporation of endogenous urea nitrogen into albumin.

\section{Case History}

The 57-year-old male patient had a Polya-Hofmeister gastrectomy in 1957 for an intractable duodenal ulcer. In 1966 he presented with a megaloblastic anaemia which responded to parenteral vitamin $\mathbf{B}_{12}$. Subsequently his main problem had

Received for publication 24 July 1974. been recurrent oedema associated with hypoalbuminaemia, but in 1971 he had had an $E$. coli septicaemia and following antibiotic treatment for this he remained free of oedema for two years. However, oedema recurred and in October 1973 he was transferred from the care of Dr N. Coghill at the West Middlesex Hospital for further investigation of hypoproteinaemia.

The main clinical features were severe cachexia, anasarca, the pigmented skin rash of protein malnutrition (Neale et al, 1967), and tender hepatomegaly. At the time of transfer his weight was $49 \mathrm{~kg}$, he had a mild hypochromic anaemia (Hb 11.7 $\mathrm{g} / 100 \mathrm{ml}$ ) with a bone marrow showing changes of iron deficiency. The Schilling test with added intrinsic factor was abnormal and the faecal fat excretion was $45 \mathrm{~g} / 24$ hours. Small intestinal biopsy carried out at the West Middlesex Hospital had been normal; liver biopsy showed marked fatty infiltration. The main biochemical results were: serum albumin $13 \mathrm{~g} / \mathrm{l}$, globulin $28 \mathrm{~g} / \mathrm{l}$, urea $4.7 \mathrm{mmol} / \mathrm{l}$ (normal 2·5-6.5), sodium 133, potassium $4 \cdot 1 \mathrm{mmol} / 1$, urinary indicans 875, $905 \mu \mathrm{mol} / 24$ hours (normal $<270$ ). Other liver and renal function tests were normal, and the gut clearance of plasma protein as measured by the $\left({ }^{51} \mathrm{Cr}\right.$ )chromic chloride test (Van Tongeren and Reichert, 1966) was normal at $30 \mathrm{ml}$ of plasma/day. A barium meal showed partial filling and stasis of a large dilated afferent gastrectomy loop. Fluid obtained by endoscopic intubation of this loop grew E. coli $\left(3 \times 10^{7}\right.$ organisms $\left./ g\right)$ and bacterioides $\left(2 \times 10^{7}\right.$ organisms $\left./ \mathrm{g}\right)$. The ${ }^{14} \mathrm{C}$-glycocholate breath test (Fromm and Hofmann, 1971) was strongly positive and both serum and jejeunal 
fluid showed high concentrations of unconjugated bile acids.

The severity of the protein malnutrition necessitated parenteral replacement therapy before further metabolic studies could be carried out. The patient was given plasma and albumin intravenously for three days, then maintained on oral feeding and supplementary intravenous nutrition with lipids and amino acids. After six weeks on this therapy the serum albumin concentration increased to $34 \mathrm{~g} / \mathrm{l}$, the oedema largely disappeared, he regained muscle strength, the skin rash faded, the liver size diminished, and there was a concomitant fall in faecal fat excretion from $45 \mathrm{~g}$ to $5 \mathrm{~g}$ /day.

At the time of the metabolic studies the serum albumin concentration had been constant for 10 days. He was being fed orally with $70 \mathrm{~g}$ of protein and 2500 calories, supplemented with a constant intravenous infusion of $5 \mathrm{~g}$ of amino-acid nitrogen/ 24 hours.

The control subject received a measured $70 \mathrm{~g}$ of protein each day in six evenly spaced meals.

\section{Materials and Methods}

\section{ISOTOPIC PREPARATIONS}

$\left[{ }^{14} \mathrm{C}\right.$ ]urea (specific radioactivity $58.1 \mathrm{mCi} / \mathrm{mmol}$, Radiochemical Centre, Amersham) was prepared as a sterile solution of $10 \mu \mathrm{Ci}$ in $10 \mathrm{ml}$ of normal saline. [ ${ }^{15} \mathrm{~N}$ ]urea $(250 \mathrm{mg} 99.6$ atoms \%, Prochem Division of British Oxygen Company) was dissolved in the $\left[{ }^{14} \mathrm{C}\right]$ urea solution just before injection and filtered through Millipore $(0 \cdot 22 \mu$ pore size). Purified human serum albumin was Millipore filtered $(0 \cdot 22 \mu)$ and labelled with ${ }^{125}$ I by the iodine monochloride method of McFarlane (1958).

\section{PROTOCOL OF INVESTIGATION}

Thyroid uptake of radioactive iodine was blocked with potassium iodide. At zero time (10.00 hours) approximately $10 \mu \mathrm{Ci}$ of [ $\left.{ }^{125 I}\right]$ albumin was injected intravenously, and immediately after taking a heparinized blood sample at $10 \mathrm{~min}$, the combined $\left[{ }^{14} \mathrm{C}\right]$ urea and $\left[{ }^{15} \mathrm{~N}\right]$ urea solution was injected intravenously. Heparinized blood samples were taken at two hourly intervals for 12 hours, and thereafter at 24-hour intervals for 10 days. The patient and a normal control volunteer received the same labelled albumin preparation. Urine was collected at measured short intervals throughout the first 24 hours, and thereafter as pooled 24-hour collections, for a further three days.

\section{MEASUREMENT OF RADIOACTIVITY}

Because ${ }^{125}$ I radioactivity overlaps with the $\beta$ spectrum of ${ }^{14} \mathrm{C}$, protein-bound iodine was pre- cipitated from $2 \mathrm{ml}$ plasma samples with an equal volume of $20 \%$ trichloroacetic acid and free iodine in the supernatant was quantitatively removed by binding to IRA 400 (BDH) resin. The supernatant equivalent of $1 \mathrm{ml}$ of plasma was brought to neutral pH with sodium hydroxide (1M) and dissolved together with $3 \mathrm{ml}$ of distilled water in $10 \mathrm{ml}$ of Unisolve (Koch-Light Laboratories) for liquid scintillation counting in an LKB spectrometer. Correction for quenching was made by the external standard-channels ratio method.

Plasma albumin ${ }^{125 I}$ radioactivity was obtained by measuring the total plasma 125I activity in aliquots of plasma and subtracting the free ${ }^{125} \mathrm{I}$ activity measured in equal aliquots of protein-free plasma supernatant.

\section{MEASUREMENT OF ${ }^{15}$ N ENRICHMENT IN ALBUMIN}

Serum albumin samples, prepared from plasma by the method of Korner and Debro (1956), were dialysed extensively against many changes of distilled water to remove labelled urea. After Kjeldahl digestion of the samples and distillation into acid, nitrogen was liberated from the samples with lithium hypobromite and analysed for its ${ }^{15} \mathrm{~N}$ content in an AEI MS20 mass spectrometer.

\section{Calculations}

\section{UREA METABOLISM}

$\left[{ }^{14} \mathrm{C}\right]$ urea specific radioactivities ( $\mathrm{dpm} / \mathrm{mg}$ of carbon) were obtained from the $\left[{ }^{14} \mathrm{C}\right]$ plasma radioactivities $(\mathrm{dpm} / \mathrm{ml})$, divided by the plasma urea carbon concentration $(\mathrm{mg} / \mathrm{ml})$. The urea pool size and urea synthetic rates were calculated from the intercept and slope of the regression line of the exponential decay curve of $\left.{ }^{[14} \mathrm{C}\right]$ urea specific radioactivity.

Since the synthesized urea, $S(\mathrm{mg} / \mathrm{hr})$, is equal to the sum of the urinary urea, $U(\mathrm{mg} / \mathrm{hr})$, and the urea degraded in the gut, $\mathbf{M}(\mathrm{mg} / \mathrm{hr})$, under steady state conditions (as defined by a constant plasma urea concentration) $\mathbf{S}=\mathbf{U}+\mathbf{M}$ and $\therefore \mathbf{M}=\mathbf{S}-\mathbf{U}$. From $M$ can be calculated the rate of release of urea nitrogen by intestinal urease, viz, every $60 \mathrm{mg}$ of urea metabolized releases $28 \mathrm{mg}$ of nitrogen.

\section{ALBUMIN METABOLISM}

The albumin intravascular:extravascular distribution ratio and the fractional catabolic rate were obtained by graphical analysis of the plasma [125I]albumin radioactivity curve by the method of Matthews (1957).

The total ${ }^{15} \mathrm{~N}$ incorporated into albumin was obtained by multiplying the plasma albumin ${ }^{15} \mathrm{~N}$ enrichment at the time of complete distribution of 
the iodine-labelled albumin by the total exchangeable albumin nitrogen pool.

\section{Results}

Although the patient had a smaller urea pool both the urea synthetic rate and the amount of urea metabolized in the gut were higher than in the control. This high non-urinary loss of urea was confirmed by recovery of only $60 \%$ of the injected $\left.{ }^{[14} \mathrm{C}\right]$ urea dose in the patient's urine, whereas the control excreted $92 \%$ of the dose (table I).

The low intravascular and total exchangeable albumin pools are associated with abnormally high fractional and absolute catabolic rates of albumin in the patient (table II). In the steady state this also implies an equally high synthetic rate.

The two lower graphs in the figure demonstrate that the albumin ${ }^{15} \mathrm{~N}$ enrichment was very much higher in the patient than in the control. Maximal enrichment was achieved between 20 and 30 hours. Thereafter the $\left[{ }^{15} \mathrm{~N}\right]$ albumin enrichment declined exponentially. Regression analysis of the decay curve gave a half-life of 10.3 days, which is considerably longer than the seven day half-life of the 125I-labelled albumin.

In the control study maximal [15 N]albumin enrichments were at the lower limit of reading of the mass spectrometer which is 0.0001 atoms \% excess. Consequently, although the peak enrichment of 0.0003 atoms \% excess is a reasonable guide to the total amount of ${ }^{15} \mathrm{~N}$ incorporated into albumin (table II), the low enrichments do not allow the
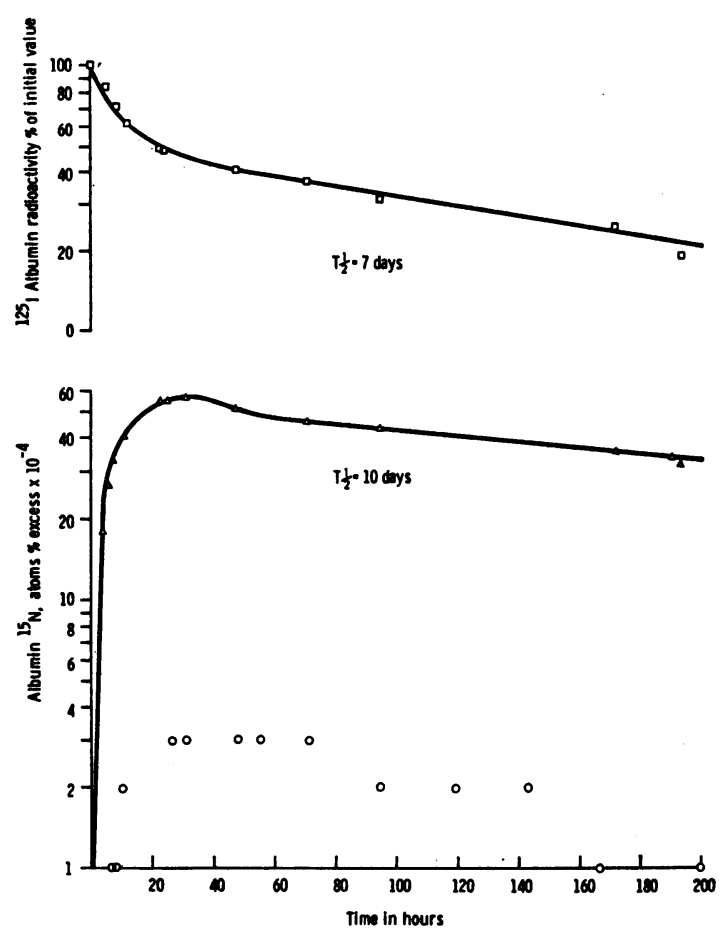

Fig Simultaneous dynamics of plasma [ ${ }^{125}$ I] albumin $(\square-\square)$ and $\left[{ }^{15} N\right]$ albumin $(\Delta-\Delta)$ in a patient with the stagnant loop syndrome who received $\left[{ }^{15} N\right]$ urea and [125I]albumin intravenously. Plasma albumin ${ }^{15} \mathrm{~N}$ enrichment in a control patient $(O)$ given the same dose of $\left[{ }^{15} N\right]$ urea is shown for comparison.

\begin{tabular}{|c|c|c|c|c|c|c|}
\hline & \multicolumn{5}{|l|}{ Urea } & \multirow{3}{*}{$\begin{array}{l}\text { Degradation Rate } \\
\text { as Percentage of } \\
\text { Urea Synthetic } \\
\text { Rate }\end{array}$} \\
\hline & \multirow[t]{2}{*}{ Total Body Pool (g) } & \multicolumn{2}{|c|}{ Synthetic Rate } & \multicolumn{2}{|c|}{ Degradation Rate } & \\
\hline & & $m g / h r$ & $m g / k g / d a y$ & $m g / h r$ & $m g / k g / d a y$ & \\
\hline $\begin{array}{l}\text { Patient } \\
\text { Control }\end{array}$ & $\begin{array}{r}7 \cdot 3 \\
12 \cdot 8\end{array}$ & $\begin{array}{l}927 \\
695\end{array}$ & $\begin{array}{l}494 \\
185\end{array}$ & $\begin{array}{r}361 \\
59\end{array}$ & $\begin{array}{r}193 \\
16\end{array}$ & $\begin{array}{r}39 \\
9\end{array}$ \\
\hline
\end{tabular}

Table I Urea metabolism in a patient with the blind loop syndrome and a normal control subject

\begin{tabular}{|c|c|c|c|c|c|c|}
\hline & \multicolumn{4}{|l|}{$\left[{ }^{226} I\right]$ Albumin } & \multicolumn{2}{|l|}{$\left[{ }^{15} N\right]$ Albumin } \\
\hline & $\begin{array}{l}\text { Intravascular } \\
\text { Albumin } \\
\text { Pool } \\
(g)\end{array}$ & $\begin{array}{l}\text { Total } \\
\text { Exchangeable } \\
\text { Albumin Pool } \\
\text { (g) }\end{array}$ & $\begin{array}{l}\text { Fractional } \\
\text { Catabolic Rate } \\
\text { (\% of Intra- } \\
\text { vascular Albumin } \\
\text { Pool/Day) }\end{array}$ & $\begin{array}{l}\text { Absolute } \\
\text { Catabolic Rate } \\
\text { (mg/kg/day) }\end{array}$ & $\begin{array}{l}10^{-4} \times \text { Atoms } \% \\
\text { Excess at Peak } \\
\text { Enrichment }\end{array}$ & $\begin{array}{l}\text { Percentage of Injected } \\
\text { Urea }{ }^{16} N \text { Found in } \\
\text { Albumin at Time of } \\
\text { Distribution of } \\
{\left[{ }^{125} I\right] \text { Albumin }}\end{array}$ \\
\hline $\begin{array}{l}\text { Patient } \\
\text { Control }\end{array}$ & $\begin{array}{r}71 \\
121\end{array}$ & $\begin{array}{l}126 \\
218\end{array}$ & $\begin{array}{l}21.4 \\
12.0\end{array}$ & $\begin{array}{l}337 \\
160\end{array}$ & $\begin{array}{r}56 \\
3\end{array}$ & $\begin{array}{l}0.9 \\
0.1\end{array}$ \\
\hline
\end{tabular}

Table II Albumin metabolic data in a patient with the stagnant loop syndrome and a normal control subject 
degradation of the $\left[{ }^{15} \mathrm{~N}\right]$ albumin to be followed accurately. However, both the albumin enrichment and the percentage of the injected ${ }^{15} \mathrm{~N}$ derived from urea appearing in albumin are very much greater in the patient than in the control.

\section{Discussion}

These results confirm previous evidence that urea reutilization is increased in the stagnant loop syndrome as a result of enhanced degradation of urea by bacterial urease (Jones et al, 1968). The present data imply that urea nitrogen is released into the gut at a rate of $4.3 \mathrm{~g}$ daily and that this nitrogen is potentially available for protein synthesis. That the liver does make increased use of this nitrogen for albumin synthesis is reflected in the relatively high $\left[{ }^{15} \mathrm{~N}\right]$ albumin enrichment in the patient as compared with the control, whose albumin enrichments were barely above the 0.0001 atoms \% excess limit of reading of the mass spectrometer. The higher incorporation may reflect not only the availability of urea nitrogen but also its more efficient utilization for albumin synthesis the rate of which was increased in the patient. Enhanced albumin synthesis may be seen after treatment with antibiotics (Jones et al, 1968) or following nitrogen supplementation with parenteral amino acids as in the present patient.

The graphs of $\left[{ }^{125} \mathrm{I}\right]$ albumin concentration and $\left[{ }^{15} \mathrm{~N}\right]$ albumin enrichment demonstrate the dissimilarity between the behaviour of these two protein labels. The radioiodine label released during degradation of the protein is excreted quantitatively in the urine, whereas the ${ }^{15} \mathrm{~N}$ label may be recycled as labelled amino-acid products of protein catabolism or as labelled urea nitrogen derived from these amino acids and from administered $\left[{ }^{15} \mathrm{~N}\right]$ urea. However, the contribution of administered urea to continuing synthesis of labelled albumin is probably small since the injected labelled urea had virtually disappeared before maximal labelling of albumin had been achieved. The short (seven-day) half-life of the iodine-labelled protein indicates a high catabolic rate of albumin. It is not known whether this is a primary event or whether it occurred following promotion of synthesis which may have occurred in response to refeeding. It is evident, however, from the normal $\left[{ }^{51} \mathrm{Cr}\right]$ chromic chloride test that the loss of protein in the gut is unlikely to be responsible for the abnormally high rate of degradation.

There are several possible explanations for the patient's high urea synthetic rate. Jones and his coworkers (1968) suggested that the heavy growth of abnormal upper intestinal flora may enhance urea synthesis by accelerating the enterohepatic recycling of ammonia nitrogen derived from urea and dietary amino acids (Schimke, 1963). Promotion of a high urea synthetic rate in the patient would also be favoured by the parenteral administration of an additional $5 \mathrm{~g}$ of nitrogen as amino acids.

Since the $\left[{ }^{14} \mathrm{C}\right]$ urea dynamics give only an approximate estimate of urea nitrogen metabolism in view of the potential for the return of labelled nitrogen into urea, and because urea nitrogen is not the immediate precursor of plasma albumin at the site of synthesis, no direct relationship between the urea degradation rate and albumin synthetic rate can be calculated. Nevertheless, in the steady state albumin synthesis at a rate of $15.2 \mathrm{~g} /$ day would require approximately $2 \cdot 4 \mathrm{~g}$ of nitrogen as substrate. Although degradation of urea alone makes available $4 \cdot 3 \mathrm{~g}$ of nitrogen daily only a small proportion of this was used for albumin synthesis.

A more precise estimate of the total incorporation of urea nitrogen into albumin was carried out by deconvolution analysis of the $\left[{ }^{15} \mathrm{~N}\right]$ albumin curve. From this it was apparent that although maximal ${ }^{15} \mathrm{~N}$ enrichment of albumin was reached by approximately 22 hours, incorporation of ${ }^{15} \mathrm{~N}$ continued throughout the entire course of the study. However, the initial major phase of incorporation was completed by 60 hours during which time $1.3 \%$ of the administered ${ }^{15} \mathrm{~N}$ entered albumin. This implies that approximately $1.3 \%(49 \mathrm{mg})$ of the body urea nitrogen pool had been incorporated into albumin in this time. Since albumin synthesis over 60 hours required $6.0 \mathrm{~g}$ of nitrogen as substrate, it can be seen that urea nitrogen made only a small contribution $(0.8 \%$ compared with the control of $0.15 \%)$. This contribution also constitutes only a small percentage of the urea nitrogen released by hydrolysis in the gut. The efficiency of reutilization of liberated urea nitrogen was therefore only $0.4 \%$. However, albumin may constitute between $20 \%$ and $25 \%$ of the protein synthetic output of the liver (Wilson, Hill, and Hoagland, 1967) so that there is potential for a relatively greater total hepatic utilization of available urea nitrogen. Although the measured urea nitrogen utilization in the patient is small in absolute terms it is much greater than in the control.

These pathologically acquired features of ruminant metabolism provide further insight into the consequences of abnormal bacterial flora in the small intestine. However, they also serve to illustrate the limitations in adaptation to such overgrowth in man. Although an increase in urea nitrogen reutilization may occur following increased bacterial urea hydrolysis, its nutritional value to the depleted nitrogen economy of the host is minimal. 
Dr Varcoe is in receipt of a fellowship from the Wellcome Trust. Our thanks are due to Dr N. Coghill for referring the patient for study, to $\mathrm{Dr}$ Jean Dolby for the quantitative microbiology of the small intestinal fluid, to Dr S. Barnes for bile acid estimations, and to Mr E. Carson for deconvolution analysis of the protein data. The patient's consent was obtained after he was fully informed of the nature of the investigation. The study was approved by the Northwick Park Hospital Ethical Committee (project number E.142).

\section{References}

Fromm, H., and Hofmann, A. F. (1971). Breath test for altered bileacid metabolism. Lancet, 2, 621-625.

Jones, E. A., Craigie, A., Tavill, A. S., Franglen, G., and Rosenoer,
V. M. (1968). Protein metabolism in the intestinal stagnant loop syndrome. Gut, 9, 466-469.

Korner, A., and Debro, J. R. (1956). Solubility of albumin in alcohol after precipitation by trichloroacetic acid: a simplified procedure for separation of albumin. Nature (Lond.), 178, 1067

Krikler, D. M., and Schrire, V. (1958), "Kwashiorkor" in an adult due to an intestinal blind loop. Lancet, 1, 510-511.

McFarlane, A. S. (1958). Efficient trace-labelling of proteins with iodine. Nature (Lond.), 182, 53.

Matthews, C. M. E. (1957). The theory of tracer experiments with 1'I-labelled plasma proteins. Phys. Med. Biol., 2, 36-53.

Neale, G., Antcliff, A. C., Welbourn, R. B., Mollin, D. L., and Booth, C. C. (1967). Protein Malnutrition after partial gastrectomy. Quart. J. Med., 36, 469-494.

Schimke, R. T. (1963). Studies on factors affecting the levels of urea cycle enzymes in the rat liver. J. biol. Chem., 238, 1012-1018.

Van Tongeren, J. H. M., and Reichert, W. J. (1966). Demonstration of protein losing gastroenteropathy: the quantitative estimation of gastrointestinal protein loss using ${ }^{51} \mathrm{Cr}$-labelled plasma proteins. Clin. chim. Acta, 14, 42-48.

Wilson, S. H., Hill, H. Z., and Hoagland, M. B. (1967). Physiology of rat-liver polysomes. Protein synthesis by stable polysomes Biochem. J., 103, 567-572. 